\title{
One Health Paradigm to Confront Zoonotic Health Threats: A Pakistan Prospective
}

\section{OPEN ACCESS}

Edited by:

Sibao Wang

Institute of Plant Physiology

and Ecology, Shanghai Institutes

for Biological Sciences, Chinese

Academy of Sciences (CAS), China

Reviewed by:

Krishna Prasad Acharya,

Department of Livestock Services,

Nepal

Lloyd Reeve-Johnson,

University of the Sunshine Coast,

Australia

Peter MacGarr Rabinowitz, University of Washington,

United States

*Correspondence:

Yahong Liu

lyh@scau.edu.cn

${ }^{\dagger}$ These authors have contributed equally to this work

Specialty section:

This article was submitted to Infectious Agents and Disease,

a section of the journal

Frontiers in Microbiology

Received: 02 June 2021 Accepted: 21 December 2021

Published: 08 February 2022

Citation:

Yasmeen $N$, Jabbar A, Shah T,

Fang L-X, Aslam B, Naseeb I,

Shakeel F, Ahmad HI, Baloch Z and

Liu Y (2022) One Health Paradigm to Confront Zoonotic Health Threats:

A Pakistan Prospective.

Front. Microbiol. 12:719334. doi: 10.3389/fmicb.2021.719334

\author{
Nafeesa Yasmeen 1,2†, Abdul Jabbar ${ }^{3 \dagger}$, Taif Shah ${ }^{3}$, Liang-xing Fang 1,2, Bilal Aslam4, \\ Iqra Naseeb5, Faiqa Shakeel'5, Hafiz Ishfaq Ahmad ${ }^{6}$, Zulqarnain Baloch $^{2}$ and \\ Yahong Liu ${ }^{1,2 *}$
}

\begin{abstract}
' National Risk Assessment Laboratory for Antimicrobial Resistance of Animal Original Bacteria, South China Agricultural University, Guangzhou, China, ${ }^{2}$ Guangdong Provincial Key Laboratory of Veterinary Pharmaceutics Development and Safety Evaluation, South China Agricultural University, Guangzhou, China, ${ }^{3}$ Faculty of Life Science and Technology, Kunming University of Science and Technology, Kunming, China, ${ }^{4}$ Department of Microbiology, Government College University, Faisalabad, Pakistan, ${ }^{5}$ Institute of Applied Microbiology, University of Veterinary and Animal Sciences, Punjab, Pakistan, ${ }^{6}$ Department of Animal Breeding and Genetics, University of Veterinary and Animal Sciences, Punjab, Pakistan
\end{abstract}

The emergence and re-emergence of zoonotic diseases significantly impact human health, particularly those who live in impoverished areas and have close contact with domestic or wild animals. Nearly $75 \%$ of zoonotic diseases are transmitted directly from animals to humans or indirectly via vector/agent interactions between animals and humans. Growing populations, globalization, urbanization, and the interaction of the environment with humans and livestock all play roles in the emergence and spread of zoonotic diseases. "One Health" is a multidisciplinary concept aimed at improving human, animal, and environmental health, but this concept is not widely accepted in developing countries. In Pakistan, environmental, human, and animal health are severely affected due to a lack of sufficient resources. This review article provides an overview of the most common zoonotic diseases found in Pakistan and emphasizes the importance of the "One Health" concept in managing these diseases. Given the current situation, interdisciplinary research efforts are required to implement and sustain effective and long-term control measures in animal, human, and environmental health surveillance and accurate diagnostic methods.

\section{Keywords: zoonotic disease, One Health, human, livestock, Pakistan}

\section{INTRODUCTION}

Zoonotic diseases (zoonoses) are caused by microbes that are naturally transmitted from animals to humans. The ongoing occurrence of zoonoses pose significant threats to public health since nearly $60 \%$ of all infectious diseases are zoonotic and animal origins account for $75 \%$ of emerging transmissible infections (Mangili et al., 2016; Supramaniam et al., 2018; Espinosa et al., 2020). Zoonotic diseases are most commonly spread through direct contact from animals to humans or indirect contact (Figure 1) via vector/agent interactions (McArthur, 2019). Global environmental changes, increased populations, urbanization, animal migration, and tourism all play roles in the emergence of zoonotic diseases (Rahman et al., 2020). The "One Health" initiative that has been 


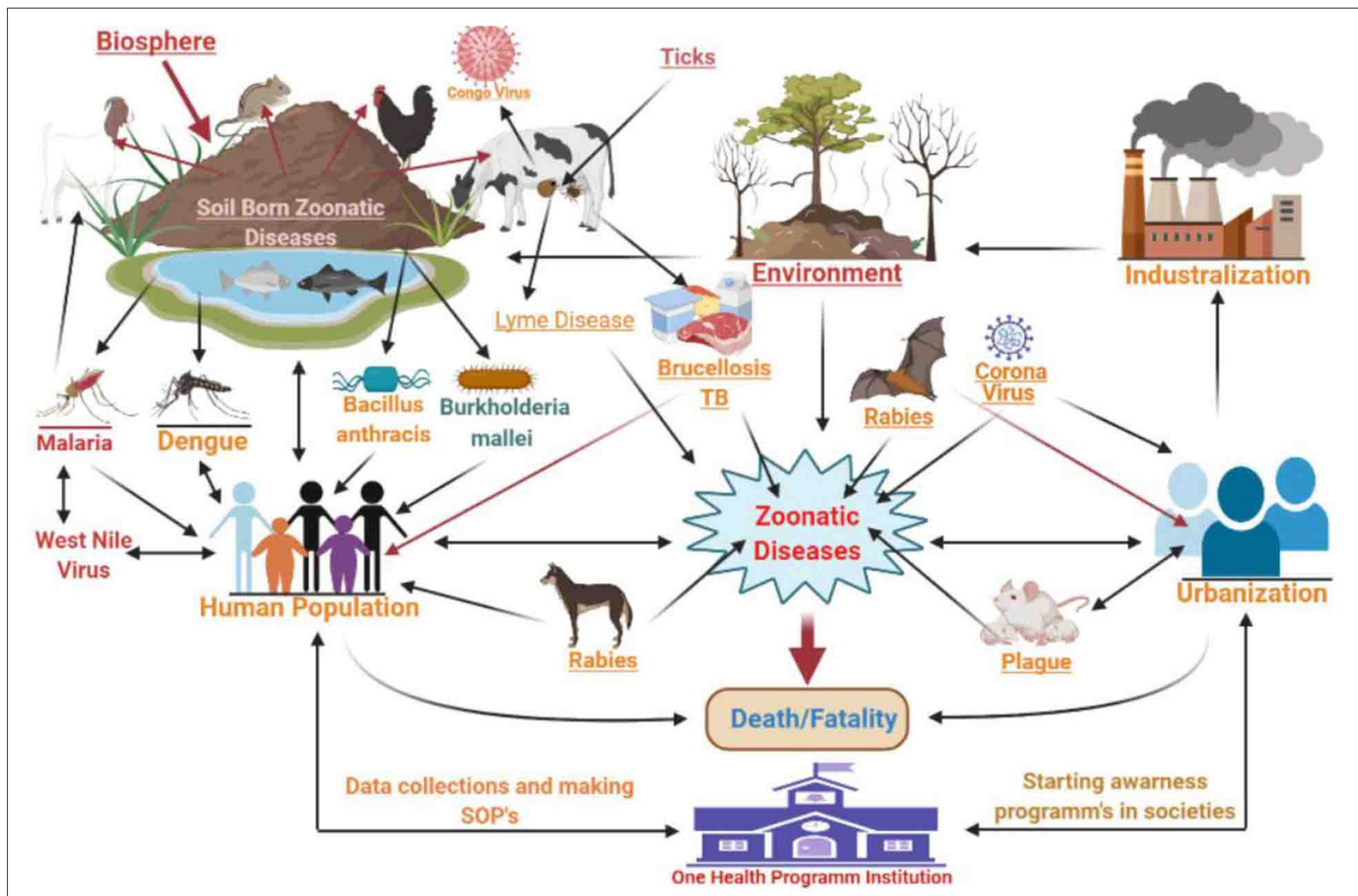

FIGURE 1 | Zoonotic diseases and One Health concept.

adopted by most industrialized countries allows for different sectors to collaborate in an effort to improve health outcomes. The goals are to promote and encourage a global health network by refining effective collaboration, cooperation, and contribution at the human-animal-environmental interface (McEwen and Collignon, 2018; Barton, 2019).

Pakistan is located near the Arabian Sea in South Asia and has the world's sixth-largest population (208 million) (Pakistan Bureau of Statistics [PBS], 2017). Pakistan's livestock population exceeds $300 \mathrm{M}$ that includes $83 \mathrm{M}$ large and $103 \mathrm{M}$ small ruminants and $147 \mathrm{M}$ poultry (Central Intelligence Agency [CIA], 2016). Regional conflicts in Afghanistan over the past 4 decades have resulted in massive refugee movements from Afghanistan to Pakistan (World Health Organization [WHO], 2004). Pakistan has a diverse natural topography, climate, and a wide range of domestic and wild animal species (Turnbull, 2008). Similarly, climate change, ecosystem diversity, poverty, social inequality, regional conflicts, and lack of a political will can all disrupt disease surveillance systems and public health (Ashraf et al., 2014).

The "One Health" concept has yet to be widely accepted in developing countries including Pakistan, where the prevalence of infectious diseases and hazardous biological materials has significantly negatively affected the environment and human and animal welfare. For example, a WHO report in 2017 documented $>800$ cases of Chikungunya virus infections in humans across Pakistan (World Health Organization [WHO], 2017). Similarly, Crimean-Congo Hemorrhagic Fever (CCHF) infected 63 people in Pakistan resulting in 11 fatalities (Altmann et al., 2019). Interactions between humans, animals, and the environment provide opportunities for pathogenic microbes to spread in any direction. Government institutions including the Ministries of Climate Change, Education, Industry and Food Safety as well as numerous non-governmental organizations (NGO) are responsible for designing and implementing innovative and practical strategies to control or prevent zoonotic diseases in Pakistan (Bartges et al., 2017). The current review provides an overview of the most common zoonotic diseases in Pakistan, and we focused on the importance of government and private sector collaborations to mitigate zoonotic threats according to the "One Health" concept.

\section{An Overview of Zoonotic Diseases in Pakistan}

In Pakistan, common zoonotic diseases include tuberculosis (TB), rabies, encephalitis, Lyme disease, CCHF, foot and 
mouth disease, Brucellosis, Q fever, Leishmaniosis, Chagas disease/Trypanosomiasis, Balantidiasis, avian influenza, Giardia, and anthrax (Table 1; Feng and Xiao, 2011; Shabbir et al., 2015; Yousaf et al., 2018; Ahmed et al., 2020b; Iqbal et al., 2020a). Soil-borne zoonotic pathogens such as Bacillus anthracis and Burkholderia mallei have been reported in humans and animals in Punjab province (Shabbir et al., 2015). Moreover, DNA-based studies have revealed that $B$. anthracis has a high prevalence in Pakistan (Shabbir et al., 2015).

A significant proportion of human TB infections throughout the 19th and 20th centuries were caused by Mycobacterium bovis and raw cow milk consumption (Jafar et al., 2014). The large Pakistani livestock population is well-adapted to local environmental conditions and the source of $1.6 \mathrm{M}$ tons of meat annually. Bovine TB infections are devastating for cattle (Jafar et al., 2014) and can transmitted to humans via aerosols in coughs, sneezes, or raw cow milk consumption. Pakistan ranks fifth among countries with a high TB burden (Shah et al., 2017) with 510,000 new TB cases emerging annually. For instance, a study of 3 primary abattoirs in Peshawar city that included lung and liver tissue samples from 121 buffaloes and 30 cattle indicated the presence of $M$. bovis in 4 cattle and 17 buffaloes with an overall prevalence of 10.18 and $11.53 \%$, respectively (Jafar et al., 2014). This high prevalence of bovine TB was linked to a lack of preventive treatments, but the presence of the diseased animals in abattoirs indicates a lack of quality veterinary inspection and monitoring for the prevention and control of animal TB. Proper inspection and monitoring should be implemented to improve the quality of animal meat and to prevent TB transmission from diseased animals to humans.

Rabies virus belongs to the Rhabdoviridae family and is one of the deadliest single-stranded RNA viruses that infect both humans and warm-blooded mammals. These infections are most prevalent in bats, dogs, and raccoons, and these species spread the infection to humans. There are 5 million cases reported annually and 50,000 fatalities due to dog bites (World Health Organization [WHO], 2018). According to the National Rabies Control Program of Pakistan (NRCP), many rural areas in Pakistan are still at high risk of rabies and $54.7 \%$ of dogs that bit humans were not vaccinated against rabies (Noureen, 2018). In addition, another report indicated that 70 canine bite victims are treated in public and private hospitals daily. Therefore, the total incidence of rabies is likely in the range of 9 million (World Health Organization [WHO], 2018).

Multiple dengue outbreaks have been reported from different regions of Pakistan during the last three decades since the first outbreak was reported in 1994 (Khan and Khan, 2015; Abdullah et al., 2019; Junaidi, 2019; Fatima et al., 2021). In particular, the 2005 outbreak in Karachi involved $>6000$ cases and 52 fatalities In 2011, in Lahore there were $>21,000$ dengue cases and 350 fatalities (Junaidi, 2019), and in 2019, 44,415 people were affected and 66 died (Junaidi, 2019). Although the prevalence rate of the dengue virus has increased yearly, the overall mortality has decreased. This milestone has been achieved with the collaborative efforts of the WHO, local public and private institutions to promote screening, door-to-door surveillance, staff training, and to conduct organized awareness sessions with the public.

Salmonella Typhi causes typhoid fever and is commonly spread via contaminated water and food as well as through animal-to-human and person-to-person contact. Every year, 11$12 \mathrm{M}$ typhoid cases are reported worldwide, and the estimated prevalence of typhoid fever is 451.7/100,000 (Ochiai et al., 2008). Therefore, there is a need for proper surveillance and monitoring strategies to control this disease (Fatima et al., 2021).

Bacillus anthracis causes anthrax and has a tremendous impact on animal health especially for cattle, sheep, and goats, and the infection is easily spread to humans. The likelihood of $B$. anthracis infections is greater in areas with many interactions between animals and humans such as slaughterhouses. An essential part of an effective disease surveillance program is animal vaccination and is needed for the prevention of future outbreaks.

Crimean-Congo Hemorrhagic Fever is one of Pakistan's most lethal tick-borne viral diseases and is characterized by fever and hemorrhage. Rapid climate change has resulted in an increased prevalence of CCHF in Pakistan due to increased industrialization, agricultural and occupational activities, and population density. Factors that contribute to CCHF spread include poor sanitation in farms, villages, and cities, the unsanitary transportation and slaughter of animals within cities, ineffective tick-control programs, nomadic lifestyles, and a lack of trained healthcare staff. CCHF is present in most major cities including Karachi, Quetta, Peshawar, and Multan, and its transmission in Pakistan is linked to a lack of an effective disease surveillance system (Yousaf et al., 2018). The general public, farmers, and healthcare workers should be educated about CCHF transmission and its consequences by local and provincial governments. Implementation of a disease surveillance system, preventive measures, detection, and treatment are all urgently required to control and eradicate this lethal disease from the country.

\section{Potential Factors Necessary to Overcome Zoonotic Disease Prevalence in Pakistan \\ Surveillance of Disease Outbreaks}

Zoonotic diseases are disseminated through animals, and disease outbreak surveillance helps to determine the cause, transmission, and pathogenesis and to guide prevention efforts (Supramaniam et al., 2018). Epidemiological surveillance is vital for population health management to determine associated risk factors responsible for disease persistence and spread. However, the collection of population-based data related to zoonotic disease prevalence in Pakistan is rare. Generally, hospital-based surveillance data has been used and indicates a high prevalence of numerous zoonotic diseases. Clinicians, epidemiologists, and specialists in environmental health and veterinary medicine can be brought together to formulate policies that address disease persistence. Awareness campaigns and vaccination programs that educate the general public should be instituted as well. Tools for programs such as these are included in the "One Health" 
TABLE 1 | List of common zoonotic diseases in Pakistan.

\begin{tabular}{|c|c|c|c|c|}
\hline Zoonotic disease & Symptoms in human & Source of transmission & Risk factors & References \\
\hline \multicolumn{5}{|c|}{ Direct transmission/contamination } \\
\hline Salmonellosis & $\begin{array}{l}\text { Fever, abdominal pain, } \\
\text { diarrhea, vomiting, nausea }\end{array}$ & $\begin{array}{l}\text { contaminated food, water, } \\
\text { livestock products, contact with } \\
\text { infected animals }\end{array}$ & $\begin{array}{l}\text { Poor living conditions, lack of } \\
\text { hygiene }\end{array}$ & $\begin{array}{l}\text { Altaf Hussain et al., 2020; } \\
\text { Petrin et al., } 2020\end{array}$ \\
\hline Anthrax & $\begin{array}{l}\text { Fever, headache, chills, nausea, } \\
\text { sore throat, swelling of the } \\
\text { neck, hoarseness, painful } \\
\text { swallowing, vomiting, diarrhea }\end{array}$ & $\begin{array}{l}\text { Bacillus anthracis: a soil-borne } \\
\text { bacteria, transmitted via } \\
\text { herbivores, spores, or via an } \\
\text { infected carcass }\end{array}$ & & $\begin{array}{l}\text { Ahmad et al., 2004; Doganay } \\
\text { and Demiraslan, 2015; Kim } \\
\text { et al., 2015; Moayeri et al., } \\
\text { 2015; Saad-Roy et al., 2017; } \\
\text { Kolton et al., } 2019\end{array}$ \\
\hline $\begin{array}{l}\text { Food-borne } E \text {. coli } \\
\text { infection }\end{array}$ & $\begin{array}{l}\text { Fever, diarrhea, vomiting, } \\
\text { respiratory disorders }\end{array}$ & $\begin{array}{l}\text { Contaminated water, food, } \\
\text { livestock products, contact with } \\
\text { infected animals }\end{array}$ & $\begin{array}{l}\text { Living conditions, lack of } \\
\text { hygiene }\end{array}$ & $\begin{array}{l}\text { Bokhari et al., 2013; Ishaq } \\
\text { et al., } 2021\end{array}$ \\
\hline Hepatitis E & $\begin{array}{l}\text { Fever, yellow skin, tiredness, } \\
\text { vomiting, nausea, abdominal } \\
\text { pain, loss of appetite, liver } \\
\text { failure }\end{array}$ & $\begin{array}{l}\text { Food and water contaminated } \\
\text { with human sewage, eating } \\
\text { uncooked pig meat }\end{array}$ & $\begin{array}{l}\text { Living conditions, lack of } \\
\text { hygiene }\end{array}$ & $\begin{array}{l}\text { Bosan et al., 2010; Butt and } \\
\text { Sharif, } 2016\end{array}$ \\
\hline Leptospirosis & $\begin{array}{l}\text { Fever, headache, nausea, loss } \\
\text { of appetite, jaundice, swollen } \\
\text { limbs, chest pain, shortness of } \\
\text { breath, coughing blood }\end{array}$ & $\begin{array}{l}\text { contaminated soil and water } \\
\text { with animal urine }\end{array}$ & $\begin{array}{l}\text { Skin lesions/injuries, } \\
\text { occupational exposure }\end{array}$ & $\begin{array}{l}\text { ljaz et al., 2018; Sohail et al., } \\
2018\end{array}$ \\
\hline Bovine TB & $\begin{array}{l}\text { Fever, weakness, loss of } \\
\text { appetite, weight loss, } \\
\text { intermittent cough, diarrhea, } \\
\text { large prominent lymph nodes }\end{array}$ & $\begin{array}{l}\text { Contaminated water, food, } \\
\text { livestock products, } \\
\text { unpasteurized dairy products, } \\
\text { direct contact with infected } \\
\text { animals }\end{array}$ & $\begin{array}{l}\text { Animal husbandry; living } \\
\text { conditions; occupational } \\
\text { exposure; wildlife reservoirs }\end{array}$ & $\begin{array}{l}\text { Awah Ndukum et al., 2010; } \\
\text { Jafar et al., } 2014\end{array}$ \\
\hline Brucellosis & $\begin{array}{l}\text { Fever, weight loss, abdominal } \\
\text { pain, weakness, body ache }\end{array}$ & $\begin{array}{l}\text { Contact with aborted fetuses, } \\
\text { vaginal fluids, placenta, milk, } \\
\text { urine, semen, feces }\end{array}$ & $\begin{array}{l}\text { Occupational exposure, } \\
\text { ingesting unpasteurized dairy } \\
\text { products }\end{array}$ & $\begin{array}{l}\text { Bilal et al., 2009; Garshasbi } \\
\text { et al., 2014; Mohammadi and } \\
\text { Golchin, 2018; Qin et al., } 2019\end{array}$ \\
\hline Rabies & $\begin{array}{l}\text { Encephalitis, hyper-excitability, } \\
\text { hydrophobia, motor neuron } \\
\text { weakness, and paralysis }\end{array}$ & Animal bites (for example, dogs) & Free-roaming dogs, rarely pets & $\begin{array}{l}\text { Ondrejková et al., 2015; } \\
\text { Jackson, 2018; Singh and } \\
\text { Ahmad, 2018; World Health } \\
\text { Organization [WHO], 2018; } \\
\text { Dascalu et al., 2019; Torquato } \\
\text { et al., } 2020\end{array}$ \\
\hline
\end{tabular}

\section{Vector-borne diseases}

Leishmaniosis

Fever, cutaneous leishmaniosis: skin lesions, weight loss, spleen, liver enlargement

Chikungunya

Crimean-Congo hemorrhagic fever

Rift Valley Fever

Foot and mouth disease
Leishmania parasite transmission via female phlebotomine sandfly bite which feeds on blood; 70 animal species are natural reservoirs, including humans This virus is maintained in the environment between humans, animals, and mosquitoes

Tick bites, contact with infected livestock
Environmental changes, urbanization, malnutrition, people migration, unhygienic lifestyle, poor health status, poverty

Aedes mosquitoes transmit the chikungunya virus from infected to healthy people.

Occupational exposure, human migration
Tiwananthagorn et al., 2012; Khan et al., 2016; Kämink et al., 2019

Ali and Dasti, 2018

Yousaf et al., 2018; Hatami et al., 2019; Kasi et al., 2020
Contact with infected livestock blood/organs, mosquito bites, unpasteurized milk

Cloven-hoofed animals, such as domestic and wild Bovidae, cattle, sheep, swine, humans
Occupational exposure

Small ruminants like sheep and goats can spread the virus
Ur-Rehman et al., 2014; Dubie and Amare, 2020 appetite, red lesions on the tongue, gums, rashes on the palms, soles, buttocks, irritability in infants and toddlers
Atif et al., 2012 
system mapping and analysis resource toolkit (Breslin et al., 2017; Brown and Nading, 2019; Iqbal et al., 2020a). In addition, routine surveillance or the continuous declaration or reporting of diseases related to public health can also play an important role in preventing zoonotic diseases (George et al., 2020). Pakistan is an agricultural country, so it is also necessary to determine the prevalence and risks associated with new zoonotic pathogens in soil, plants, vegetables, and fruits and to have formulated an action plan for their prevention (Ahmed et al., 2017).

\section{Environmental Change and the "One Health" Concept}

Human expansion has increased atmospheric carbon emissions, resulting in an elevation of the global temperature that has disrupted normal lifecycles and ecosystems. Urbanization has accelerated the close contact of humans with animals such as squirrels, mice, jackals, foxes, and pigs. These are favorable circumstances for the emergence or re-emergence of zoonotic diseases (Sleeman et al., 2019). Deforestation and the loss of ecosystem diversity, air pollution from crop and coal combustion, melting ice due to global warming, extremes of temperature, over-population, increased humidity and temperatures, and decreased food production are having catastrophic effects on the natural diversity of the environment. These conditions also aid zoonotic pathogen survival and spread (El-Sayed and Kamel, 2020; Majeed and Munir, 2020). For instance, humidity and temperature directly influence the spread of the coronavirus through aerosols and the virus can be found in an active state for at least 2 weeks on most surfaces (Lin et al., 2020).

In Pakistan, inadequate infectious waste management is a major source of contamination in communities and facilitates infectious disease dissemination on a wide scale. Many hospitals and industries do not separate different types of waste materials such as chemicals, pulp, biologicals, textiles, and leather. These pollutants can act as carriers of hepatitis A and E, intestinal pathogens such as Salmonella, and acute respiratory disease pathogens (Rab et al., 1997; Qasim et al., 2014). The lack of proper industrial, hospital, farm, and household disposal can combine with natural events such as floods to contaminate drinking water supplies (Daud et al., 2017).

Enteric zoonotic diseases are often transmitted by the food chain and the environment (Klumb et al., 2020) such as bacteria residing in contaminated soil and surface waters (Vincent et al., 2019). Wildlife can also spread zoonotic pathogens to humans (Rothenburger et al., 2019). Disease burden is also tightly linked to poverty in Pakistan, and examples are dengue, Vibrio cholera, malaria, Lyme disease, COVID-19, influenza virus, respiratory syncytial virus, TB, and skin cancer (Baudouin et al., 2002; Patz et al., 2003; Khaliq et al., 2015; Velraj and Haghighat, 2020). Disease transmission due to the improper disposal of hazardous materials can be prevented, and this can begin at the community hospital level and successes can be used as examples for other areas including improvements for public trash disposal and limiting agricultural and industrial runoff (Ali, 2018; Hussain et al., 2020; Majeed and Munir, 2020). The "One Health" process has strategic plans that can be implemented to achieve these targets (Cunningham et al., 2017).

\section{Animals and Food Safety}

The prevalence of food-borne infections caused by Listeria monocytogenes, Campylobacter spp., Salmonella spp., Toxoplasma gondii, and Norovirus is common in Pakistan (Nisar et al., 2018). Furthermore, food is exposed to a variety of toxic chemicals during its preparation, processing, handling, and storage (Javed, 2016; Ishaq et al., 2021). Pakistan is one of the top milk and halal meat-producing states in the world, although the quality of these products is often not good. Therefore, diseases such as brucellosis and bovine TB begin at the farm level are transmitted during animal handling, milking, slaughtering, and processing (Claeys et al., 2013). The most successful method for improving milk production is pasteurization. Residual antibiotics as well as microbes and other contaminants in milk can be easily screened using Raman spectroscopic techniques (He et al., 2019). Pasteurization extends the shelf life of milk, and untreated or raw milk can contain infectious pathogens. Therefore, the latest milk production and processing techniques must be implemented on a country-wide basis to control milk-related zoonotic disease transmission in Pakistan.

Meat is a primary protein source and is consumed massively all over the world. The spread of food-borne illnesses such as Bovine Spongiform Encephalopathy (BSE), hepatitis, and typhoid has been linked to inappropriate meat processing (Ozawa, 2003; Javed, 2016), and standard operating procedures for farm and abattoir sanitation are necessary for healthy meat production. Environmental health practitioners play a crucial role in meat safety and the fulfillment of hygienic conditions. Food inspections are also required for meat labeled for export, and technologies like multiplex PCR for meat screening are relatively easy to implement (Iqbal et al., 2020b). All these safety procedures also apply to organic food production (Akbar et al., 2019). Safe meat for the consumer requires that quality standards are applied to animal handling, slaughtering, dressing, and storage (Ishaq et al., 2021).

\section{Vectors and Their Controls}

Climate change is a key player in the global spread of vectorborne diseases. According to WHO estimates, climate change will most likely cause 250,000 extra deaths annually due to malaria, malnutrition, heat stress, and diarrhea from 2030 to 2050. These climatic alterations result in heavy and unpredictable rainfalls, flooding, and high humidity, and all these are conducive for the propagation of disease vectors such as rodents, fleas, and mosquitoes (Ngeleja et al., 2017). Furthermore, air pollution from excessive gas emissions, the greenhouse effect, increased hydrocarbon combustion, and deforestation all contribute to a greater risk for zoonotic disease transmission (Rossati, 2017). Approximately half of the human population is at risk of vector-borne disease, and these diseases account for $>17 \%$ of all infectious diseases and $1 \mathrm{M}$ deaths worldwide each year. Increased temperature and humidity levels are linked to the surge in the prevalence of insect vector-borne diseases such as malaria, plaque, leishmaniosis, African trypanosomiasis, Japanese 
encephalitis, and diseases of viral origin like Rift Valley Fever. Additionally, health professional negligence has also been cited as a contributing factor to increased disease prevalence (Fouque and Reeder, 2019).

Pakistan is vulnerable to the impacts of climate change. The exact figure of vector-borne diseases in Pakistan is unclear, although there are currently 1.5 million malaria cases in Pakistan and these levels are comparable to Somalia, Afghanistan, and Djibouti. Inadequate housing, water, sanitation, and limited access to health facilities are the most direct possible causes of the prevalence of vector-borne diseases in Pakistan. The reemergence of Leishmaniosis caused by the female phlebotomine sand fly (Khan et al., 2019), CCHF acquired via tick bites (Altmann et al., 2019), and Rift Valley Fever via mosquito bites or consumption of unpasteurized milk (Fouque and Reeder, 2019) are the major causes for morbidity and mortality levels that can all be addressed by the "One Health" Initiative. New strategies and collaborations with health administrations, the environmental ministry, entomologists, zoologists, veterinarians, and NGOs can assist vector-borne zoonotic disease management in Pakistan (Bostan et al., 2017; Huang et al., 2019).

\section{Importance of Health Education}

Health education is the building block of "One Health" where its motto is to educate the public about their health. Factors such as malnourishment, food insecurity, poverty, crowding, late reporting of disease, and poor observance of sanitary treatment measures as well as lack of vaccination and contaminated drinking water are major obstacles in securing Pakistan's health security. In March 2002, 300 attorneys from 35 countries gathered to increase awareness and provide alertness related to environmental hazards and their effects on public health. Healthcare facilities should be updated in Pakistan, and awareness of these problems must be communicated through human resources to improve management systems particularly in rural areas (Ahmed and Shaikh, 2011). Information concerning food safety awareness and dietary guidelines to prevent zoonotic disease should be readily available to the general public. Further, policies for the improvement of farm production, sanitation, and food storage conditions should be implemented. Local authorities can develop collaborations with the Ministry of Health and Livestock for proper vaccination against zoonotic diseases, and overall, these measures will improve public health (Suk et al., 2003). This type of process would also assist in educating farmers and consumers in maintaining animal health. The focus on education is crucial because an understanding of a process is more likely to result in the acceptance of the values suggested by health services. But unfortunately, the Pakistani community is less likely to be aware of the basic issues due to a low literacy rate and a lack of understanding of how diseases spread and how these are connected with health parameters, socio-cultural and environmental problems, as well as political issues. Therefore, to overcome and halt this dangerous situation, it is necessary to adopt, enforce, and implement awareness campaigns especially related to health-seeking behavior and conduct in person surveys and develop assessment exercises with private and public sector collaborators (Shaikh and Hatcher, 2005; Zahid, 2018).

\section{Population Density}

The close association of humans and their livestock is linked to the transmission of zoonotic pathogens (Kilpatrick and Randolph, 2012; Suk et al., 2014), and these risks are elevated in areas where animals and humans share living areas (Nieto et al., 2012; Owczarczak-Garstecka, 2018) and those with inadequate sanitation facilities (Gayer et al., 2007; Warraich et al., 2011). When a disease has become established in a human population (Paterson et al., 2018; Braam et al., 2021), sedentary conditions in camps and informal settlements increase the risk of zoonotic pathogen transmission and population size and density affect a pathogen's ability to infect susceptible hosts (Brooker et al., 2004; Hammer et al., 2018). Strengthening the standards for improving hygiene and sanitation in local food markets will decrease the risk of zoonotic disease transmission. In market settings, policies for crowd control, physical distancing measures, and handwashing and sanitizing stations should be implemented and enforced.

\section{Poverty and Socio-Economic Inequities}

Poverty and socioeconomic inequalities are associated with poor health (Vincent, 2016; Khan and Hussain, 2020). Disasters and displacement affect access to education, employment, and lifestyle choices and exacerbates poverty (Du et al., 2018). Displaced populations are frequently subjected to structural discrimination, violence, and a lack of equitable access to services (Castañeda et al., 2015). Furthermore, displaced communities are frequently located in geographically marginalized areas with limited resources (McMichael et al., 1998). For example, communities along the Pakistan-Afghan border bear the brunt of vector-borne disease due to human displacement (Nieto et al., 2012). Numerous events should encourage dialogue and collaboration with local representatives, academics, policymakers, and medical practitioners. Seminars and conferences should be held in various cities to raise public awareness about disease prevention, protect and strengthen investments in health and unemployment insurance, make tax systems less regressive, safeguard worker rights, and expand medical care facilities.

\section{Importance of Food and Water Safety and Its Hygiene Practices}

Food is an important source of zoonotic disease. Zoonoses with a food-borne reservoir are typically caused by consuming food or contaminated water. Additionally, many zoonotic microbes exist in the gastrointestinal tracts of food-producing animals and poses a farm to fork risk of contamination. Therefore, food safety is a major concern for global public health (Gizaw, 2019) and pro-active strategies are required to mitigate the spread of these diseases (Chapman and Gunter, 2018; Ishaq et al., 2021). Food handling is a major factor in controlling the spread of foodborne diseases. It has always been challenging to control zoonotic diseases in countries (Ma et al., 2019), particularly Pakistan, where food is commonly sold in the streets under unsanitary conditions. Additionally, food safety knowledge in the general population is poor (Ma et al., 2019). These factors elevate the risk of zoonotic diseases such as the major pathogens Salmonella, Campylobacter, Listeria, E. coli O157:H7, Bacillus cereus, and 
Clostridium (Lammie and Hughes, 2016; Samad et al., 2018). The "One Health" concept promotes the wellbeing of humans and animals including farm and wild animals. This concept can decrease the prevalence of most food-borne diseases by using the combined efforts of environmental health professionals.

Water is the most fundamental resource, and pure drinking water is one of the most important components for life (Pandey, 2006). Unsafe or contaminated water can expose animals and humans to pathogens and pollutants resulting in gastrointestinal, neurological, and reproductive disorders (Lee and Murphy, 2020). Most of the water resources in the world have been polluted due to urbanization, industrialization, and environmental changes (Pandey, 2006). Therefore, approximately 2.2 billion people are using unsafe drinking water in the world (World Health Organization [WHO], 2019).

Pakistan is a developing country located in South Asia. Urbanization, industrialization, and population growth have polluted water resources in Pakistan. Therefore, only $20 \%$ of the population has access to safe drinking water in Pakistan (Daud et al., 2017). In terms of potable water quality, Pakistan has been ranked 80 th out of 122 countries. If water quality issues are not addressed, then a $60 \%$ potable water shortage may soon be confronted due to the mixing of community, sewerage, and industrial waste without treatment (Aziz, 2005; Azizullah et al., 2011; Bhowmik et al., 2015; Khalid et al., 2018; Ilyas et al., 2019). In 2020, 400+ schools were randomly tested in Pakistan to examine the quality of the water and $>50 \%$ of the samples were contaminated with highly pathogenic microorganisms (Ahmed et al., 2020a). Another study reported that drinking water in Sibi district, Baluchistan was highly contaminated with fluoride and arsenic (Chandio et al., 2020). Contaminated or untreated water originating from agriculture is also a major issue in Pakistan (Shahid et al., 2020), and crops produced from contaminated water are not fit for human consumption. In Pakistan, water supplies have been adversely influenced by climate change, chemical and biological pollutants due to pipe cracks, poor sewage systems, and a lack of water quality control testing systems (Aziz, 2005). Governments and NGOs have adopted different rules and regulations to control the risk of water contamination such as the WASH interventions, Water and Sanitation Extension Programs (WASEP) projects, Oxfam GB, Quantitative Microbiological Risk Assessment (QMRA), Punjab Saaf Pani project, and the Changa Pani scheme (Nanan et al., 2003; Baig et al., 2012; Ahmed et al., 2020a,c; Als et al., 2020). WASEP projects are particularly enforced at the rural level to enhance or rectify water supplies for consumers (Nanan et al., 2003). Similarly, the NGO Oxfam GB is putting its efforts into evaluating major problems associated with the quality of potable water (Baig et al., 2012). In addition, the Punjab Saaf Pani and Changa Pani projects are contributing to the improvement of water quality in rural and urban areas (Ahmed et al., 2020c).
Organizations such as the Pakistan Environmental Protection Council (PEPC) and the Pakistan Environmental Protection Agency (Pak-EPA) are contributing their efforts to implementing protective standards such as the National Environmental Quality Standard (NEQS). The primary concern is how to perform technical assessments of water quality and provide microbiologically certified safe water by following the recommended procedures of the Environment, Health and Safety (EHS) ministry. Unfortunately, these organizations were unable to apply those environmental safety standards to all industrial and non-industrial sectors (Azizullah et al., 2011). This situation can be remedied by implementing suitable holistic solutions and legislation through proper monitoring systems in all national, local, and individual sectors.

\section{CONCLUSION}

Zoonotic diseases pose the largest challenge for developing countries because humans, animals, and the environment all play roles in their transmission. Pakistan faces huge challenges due to a lack of strategic planning for responses to zoonotic disease infections. The "One Health" strategy can assist governmental agencies such as the Ministries of Climate Change, Education, Industry and Production and Food Safety by collaborating with the private sector and NGOs to adopt innovative and practical plans to control or prevent zoonotic diseases in Pakistan. The environmental health and food supply chains require a "One Health" approach to deal with zoonotic diseases (Lammie and Hughes, 2016).

\section{AUTHOR CONTRIBUTIONS}

YL designed the study. NY, AJ, and ZB wrote the initial version of the manuscript. ZB, TS, L-XF, and BA revised the final draft of the manuscript. IN, FS, and HA searched the literature and designed the table and figure.

\section{FUNDING}

This study was supported by grants from "Guangdong Special Support Program innovation team 2019BT02N054" and the Major Science and Technology Special Project of Yunnan Province, No. 2019ZF004.

\section{ACKNOWLEDGMENTS}

We thank all the participants involved in this study. 


\section{REFERENCES}

Abdullah, Ali, S., Salman, M., Din, M., Khan, K., Ahmad, M., et al. (2019). Dengue Outbreaks in Khyber Pakhtunkhwa (KPK), Pakistan in 2017: an Integrated Disease Surveillance and Response System (IDSRS)-Based Report. Pol. J. Microbiol. 68, 115-119. doi: 10.21307/pjm2019-013

Ahmad, K., Kazi, B., Us-Saba, N., Ansari, J., and Nomani, K. (2004). Pakistan's experience of a bioterrorism-related anthrax scare. East. Mediterr. Health J. 10, 19-26.

Ahmed, H., Ali, S., Afzal, M. S., Khan, A. A., Raza, H., Shah, Z. H., et al. (2017). Why more research needs to be done on echinococcosis in Pakistan. Infect. Dis. Poverty 6, 1-5. doi: 10.1186/s40249-017-0309-z

Ahmed, J., and Shaikh, B. (2011). The state of affairs at primary health care facilities in Pakistan: where is the State's stewardship? East. Mediterr. Health J. $17,619-623$.

Ahmed, T., Hussain, S., Rinchen, S., Yasir, A., Ahmed, S., Khan, W. A., et al. (2020b). Knowledge, attitude and practice (KAP) survey of canine rabies in Khyber Pakhtunkhwa and Punjab Province of Pakistan. BMC Public Health 20:1293. doi: 10.1186/s12889-020-09388-9

Ahmed, J., Wong, L. P., Chua, Y. P., Channa, N., Mahar, R. B., Yasmin, A., et al. (2020a). Quantitative Microbial Risk Assessment of Drinking Water Quality to Predict the Risk of Waterborne Diseases in Primary-School Children. Int. J. Environ. Res. Public Health 17:2774. doi: 10.3390/ijerph17082774

Ahmed, T., Zounemat-Kermani, M., and Scholz, M. (2020c). Climate change, water quality and water-related challenges: a review with focus on Pakistan. Int. J. Environ. Res. Public Health 17:8518. doi: 10.3390/ijerph17228518

Akbar, A., Ali, S., Ahmad, M. A., Akbar, M., and Danish, M. (2019). Understanding the Antecedents of Organic Food Consumption in Pakistan: moderating Role of Food Neophobia. Int. J. Environ. Res. Public Health 16:4043. doi: 10.3390/ ijerph16204043

Ali, I., and Dasti, J. I. (2018). Chikungunya virus; an emerging arbovirus in Pakistan. J. Pak. Med. Assoc. 68, 252-257.

Ali, M. (2018). Field lessons in surveying healthcare waste management activities in Pakistan. East. Mediterr. Health J. 25, 213-217. doi: $10.26719 /$ emhj. 18.024

Als, D., Meteke, S., Stefopulos, M., Gaffey, M. F., Kamali, M., Munyuzangabo, M., et al. (2020). Delivering water, sanitation and hygiene interventions to women and children in conflict settings: a systematic review. BMJ Glob. Health 5:e002064. doi: 10.1136/bmjgh-2019-002064

Altaf Hussain, M., Wang, W., Sun, C., Gu, L., Liu, Z., Yu, T., et al. (2020). Molecular Characterization Of Pathogenic Salmonella Spp From Raw Beef In Karachi, Pakistan. Antibiotics 9:73. doi: 10.3390/antibiotics9020073

Altmann, M., Nahapetyan, K., and Asghar, H. (2019). Identifying hotspots of viral haemorrhagic fevers in the Eastern Mediterranean Region: perspectives for the Emerging and Dangerous Pathogens Laboratory Network. East. Mediterr. Health J. 24, 1049-1057. doi: 10.26719/emhj.18.002

Ashraf, S., Chaudhry, H. R., Chaudhry, M., Iqbal, Z., Ali, M., Jamil, T., et al. (2014). Prevalence of common diseases in camels of Cholistan desert, Pakistan. IUFS J. Biol. 2, 49-52. doi: 10.1016/j.micpath.2017.04.011

Atif, F. A., Khan, M. S., Iqbal, H. J., Ali, Z., and Ullah, S. (2012). Prevalence of cattle tick infestation in three districts of the Punjab, Pakistan. Pak. J. Sci. 64, 49-53.

Awah Ndukum, J., Kudi, A. C., Bradley, G., Ane-Anyangwe, I. N., Fon-Tebug, S., and Tchoumboue, J. (2010). Prevalence of bovine tuberculosis in abattoirs of the littoral and Western highland regions of cameroon: a cause for public health concern. Vet. Med. Int. 2010:495015. doi: $10.4061 / 2010 / 495015$

Aziz, J. (2005). Management of source and drinking-water quality in Pakistan. EMHJ-East. Mediterr. Health J. 11, 1087-1098.

Azizullah, A., Khattak, M. N. K., Richter, P., and Häder, D.-P. (2011). Water pollution in Pakistan and its impact on public health-a review. Environ. Int. 37, 479-497. doi: 10.1016/j.envint.2010.10.007
Baig, S. A., Xu, X., and Khan, R. (2012). Microbial water quality risks to public health: potable water assessment for a flood-affected town in northern Pakistan. Rural Remote Health 12:2196.

Bartges, J., Kushner, R. F., Michel, K., Sallis, R., and Day, M. (2017). One health solutions to obesity in people and their pets. J. Comp. Pathol. 156, 326-333. doi: 10.1016/j.jcpa.2017.03.008

Barton, B. C. (2019). Introduction. One Health: over a decade of progress on the road to sustainability. Rev. Sci. Tech. 38, 21-50. doi: 10.20506/rst.38.1.2939

Baudouin, C., Charveron, M., Tarroux, R., and Gall, Y. (2002). Environmental pollutants and skin cancer. Cell Biol. Toxicol. 18, 341-348. doi: 10.1023/a: 1019540316060

Bhowmik, A. K., Alamdar, A., Katsoyiannis, I., Shen, H., Ali, N., Ali, S. M., et al. (2015). Mapping human health risks from exposure to trace metal contamination of drinking water sources in Pakistan. Sci. Total Environ. 538, 306-316. doi: 10.1016/j.scitotenv.2015.08.069

Bilal, C., Khan, M., Avais, M., Ijaz, M., and Khan, J. (2009). Prevalence and chemotherapy of Balantidium coli in cattle in the River Ravi region, Lahore (Pakistan). Vet. Parasitol. 163, 15-17. doi: 10.1016/j.vetpar.2009.04.023

Bokhari, H., Shah, M. A., Asad, S., Akhtar, S., Akram, M., and Wren, B. W. (2013). Escherichia coli pathotypes in Pakistan from consecutive floods in 2010 and 2011. Am. J. Trop. Med. Hyg. 88, 519-525. doi: 10.4269/ajtmh.12-0365

Bosan, A., Qureshi, H., Bile, K. M., Ahmad, I., and Hafiz, R. (2010). A review of hepatitis viral infections in Pakistan. J. Pak. Med. Assoc. 60, 1045-1058.

Bostan, N., Javed, S., Nabgha, E. A., Eqani, S. A., Tahir, F., and Bokhari, H. (2017). Dengue fever virus in Pakistan: effects of seasonal pattern and temperature change on distribution of vector and virus. Rev. Med. Virol. 27:e1899. doi: 10.1002/rmv.1899

Braam, D. H., Jephcott, F. L., and Wood, J. L. N. (2021). Identifying the research gap of zoonotic disease in displacement: a systematic review. Glob. Health Res. Policy 6:25. doi: 10.1186/s41256-021-00205-3

Breslin, G., Shannon, S., Haughey, T., Donnelly, P., and Leavey, G. (2017). A systematic review of interventions to increase awareness of mental health and well-being in athletes, coaches and officials. Syst. Rev. 6:177. doi: 10.1186/ s13643-017-0568-6

Brooker, S., Mohammed, N., Adil, K., Agha, S., Reithinger, R., Rowland, M., et al. (2004). Leishmaniasis in refugee and local Pakistani populations. Emerg. Infect. Dis. 10, 1681-1684. doi: 10.3201/eid1009.040179

Brown, H., and Nading, A. M. (2019). Introduction: human animal health in medical anthropology. Med. Anthropol. Q. 33, 5-23. doi: $10.1111 / \mathrm{maq} .12488$

Butt, A. S., and Sharif, F. (2016). Viral Hepatitis in Pakistan: past, Present, and Future. Euroasian J. Hepatogastroenterol. 6, 70-81. doi: 10.5005/jp-journals10018-1172

Castañeda, H., Holmes, S. M., Madrigal, D. S., Young, M. E., Beyeler, N., and Quesada, J. (2015). Immigration as a social determinant of health. Annu. Rev. Public Health 36, 375-392.

Central Intelligence Agency [CIA] (2016). The World Factbook. Langley, Virginia: Central Intelligence Agency

Chandio, T. A., Khan, M. N., Muhammad, M. T., Yalcinkaya, O., Wasim, A. A., and Kayis, A. F. (2020). Fluoride and arsenic contamination in drinking water due to mining activities and its impact on local area population. Environ. Sci. Pollut. Res. 28, 1-14. doi: 10.1007/s11356-020-10575-9

Chapman, B., and Gunter, C. (2018). "Local food systems food safety concerns," in Preharvest Food Safety, eds S. Thakur and K. E. Kniel (Hoboken: John Wiley \& Sons, Inc), 249-260. doi: 10.1128/microbiolspec.PFS-0020-2017

Claeys, W. L., Cardoen, S., Daube, G., De Block, J., Dewettinck, K., Dierick, K., et al. (2013). Raw or heated cow milk consumption: review of risks and benefits. Food Control 31, 251-262.

Cunningham, A. A., Daszak, P., and Wood, J. L. (2017). One Health, emerging infectious diseases and wildlife: two decades of progress? Philos. Trans. R. Soc. B Biol. Sci. 372:20160167. doi: 10.1098/rstb.2016.0167 
Dascalu, M. A., Wasniewski, M., Picard-Meyer, E., Servat, A., Bocaneti, F. D., Tanase, O. I., et al. (2019). Detection of rabies antibodies in wild boars in northeast Romania by a rabies ELISA test. BMC Vet. Res. 15:466. doi: 10.1186/s12917019-2209-x

Daud, M., Nafees, M., Ali, S., Rizwan, M., Bajwa, R. A., Shakoor, M. B., et al. (2017). Drinking water quality status and contamination in Pakistan. Biomed Res. Int. 2017:7908183. doi: $10.1155 / 2017 / 7908183$

Doganay, M., and Demiraslan, H. (2015). Human anthrax as a re-emerging disease. Recent Pat. Anti-Infect. Drug Discov. 10, 10-29. doi: 10.2174/ $1574891 \times 10666150408162354$

Du, R. Y., Stanaway, J. D., and Hotez, P. J. (2018). Could violent conflict derail the London Declaration on NTDs? PLoS Negl. Trop. Dis. 12:e0006136. doi: 10.1371/journal.pntd.0006136

Dubie, T., and Amare, T. (2020). Isolation, Serotyping, and Molecular Detection of Bovine FMD Virus from Outbreak Cases in Aba'ala District of Afar Region, Ethiopia. Vet. Med. Int. 2020:8847728. doi: $10.1155 / 2020 / 8847728$

El-Sayed, A., and Kamel, M. (2020). Climatic changes and their role in emergence and re-emergence of diseases. Environ. Sci. Pollut. Res. 27, 22336-22352. doi: 10.1007/s11356-020-08896-w

Espinosa, R., Tago, D., and Treich, N. (2020). Infectious diseases and meat production. Environ. Resour. Econ. 76, 1019-1044. doi: 10.1007/s10640-02000484-3

Fatima, M., Kumar, S., Hussain, M., Memon, N. M., Vighio, A., Syed, M. A., et al. (2021). Morbidity and Mortality Associated with Typhoid Fever Among Hospitalized Patients in Hyderabad District, Pakistan, 20172018: retrospective Record Review. JMIR Public Health Surveill. 7:e27268. doi: $10.2196 / 27268$

Feng, Y., and Xiao, L. (2011). Zoonotic potential and molecular epidemiology of Giardia species and giardiasis. Clin. Microbiol. Rev. 24, 110-140. doi: 10.1128/ CMR.00033-10

Fouque, F., and Reeder, J. C. (2019). Impact of past and on-going changes on climate and weather on vector-borne diseases transmission: a look at the evidence. Infect. Dis. Poverty 8, 1-9. doi: 10.1186/s40249-019-0565-1

Garshasbi, M., Ramazani, A., Sorouri, R., Javani, S., and Moradi, S. (2014) Molecular detection of Brucella species in patients suspicious of Brucellosis from Zanjan, Iran. Braz. J. Microbiol. 45, 533-538. doi: 10.1590/s151783822014005000048

Gayer, M., Legros, D., Formenty, P., and Connolly, M. A. (2007). Conflict and emerging infectious diseases. Emerg. Infect. Dis. 13, 1625-1631.

George, J., Häsler, B., Mremi, I., Sindato, C., Mboera, L., Rweyemamu, M., et al. (2020). A systematic review on integration mechanisms in human and animal health surveillance systems with a view to addressing global health security threats. One Health Outlook 2, 1-15. doi: 10.1186/s42522-020-00017-4

Gizaw, Z. (2019). Public health risks related to food safety issues in the food market: a systematic literature review. Environ. Health Prev. Med. 24:68. doi: 10.1186/s12199-019-0825-5

Hammer, C. C., Brainard, J., and Hunter, P. R. (2018). Risk factors and risk factor cascades for communicable disease outbreaks in complex humanitarian emergencies: a qualitative systematic review. BMJ Glob. Health 3:e000647. doi: 10.1136/bmjgh-2017-000647

Hatami, H., Qaderi, S., and Omid, A. M. (2019). Investigation of Crimean-Congo hemorrhagic fever in patients admitted in Antani Hospital, Kabul, Afghanistan, 2017-2018. Int. J. Prev. Med. 10:117. doi: 10.4103/ijpvm.IJPVM_391_18

He, H., Sun, D.-W., Pu, H., Chen, L., and Lin, L. (2019). Applications of Raman spectroscopic techniques for quality and safety evaluation of milk: a review of recent developments. Crit. Rev. Food Sci. Nutr. 59, 770-793. doi: 10.1080/ 10408398.2018.1528436

Huang, Y.-J. S., Higgs, S., and Vanlandingham, D. L. (2019). Emergence and reemergence of mosquito-borne arboviruses. Curr. Opin. Virol. 34, 104-109. doi 10.1016/j.coviro.2019.01.001

Hussain, M., Butt, A. R., Uzma, F., Ahmed, R., Irshad, S., Rehman, A., et al. (2020). A comprehensive review of climate change impacts, adaptation, and mitigation on environmental and natural calamities in Pakistan. Environ. Monit. Assess. 192:48. doi: 10.1007/s10661-019-7956-4
Ijaz, M., Abbas, S. N., Farooqi, S. H., Aqib, A. I., Anwar, G. A., Rehman, A., et al. (2018). Sero-epidemiology and hemato-biochemical study of bovine leptospirosis in flood affected zone of Pakistan. Acta Trop. 177, 51-57. doi: 10.1016/j.actatropica.2017.09.032

Ilyas, M., Ahmad, W., Khan, H., Yousaf, S., Yasir, M., and Khan, A. (2019). Environmental and health impacts of industrial wastewater effluents in Pakistan: a review. Rev. Environ. Health 34, 171-186. doi: 10.1515/reveh-20180078

Iqbal, M., Fatmi, Z., and Khan, M. A. (2020a). Brucellosis in Pakistan: a neglected zoonotic disease. JPMA J. Pak. Med. Assoc. 70, 1625-1626. doi: 10.5455/JPMA. 24139

Iqbal, M., Saleem, M. S., Imran, M., Khan, W. A., Ashraf, K., Yasir Zahoor, M., et al. (2020b). Single tube multiplex PCR assay for the identification of banned meat species. Food Addit. Contam. Part B Surveill. 13, 284-291. doi: 10.1080/ 19393210.2020.1778098

Ishaq, A. R., Manzoor, M., Hussain, A., Altaf, J., Rehman, S. U., Javed, Z., et al. (2021). Prospect of microbial food borne diseases in Pakistan: a review. Braz. J. Biol. 81, 940-953. doi: 10.1590/1519-6984.232466

Jackson, A. (2018). Rabies: a medical perspective. Rev. Sci. Tech. 37, 569-580. doi: $10.20506 /$ rst.37.2.2825

Jafar, K., Sultan, A., Abd El-Salam, N. M., Riaz, U., and Taif, S. (2014). Prevalence of tuberculosis in buffalo and cattle. J. Pure Appl. Microbiol. 8, 721-726.

Javed, A. (2016). Food Borne Health issues and their relevance to Pakistani society. Am. Sci. Res. J. Eng. Technol. Sci. 26, 235-251.

Junaidi, I. (2019). Dengue outbreak sets new record in Pakistan. Pakistan: Dawn.

Kämink, S., Abdi, A., Kamau, C., Ashraf, S., Ansari, M. A., Qureshi, N. A., et al. (2019). Failure of an innovative low-cost, noninvasive thermotherapy device for treating cutaneous leishmaniasis caused by leishmania tropica in Pakistan. Am. J. Trop. Med. Hyg. 101, 1373-1379. doi: 10.4269/ajtmh.19-0430

Kasi, K. K., von Arnim, F., Schulz, A., Rehman, A., Chudhary, A., Oneeb, M., et al. (2020). Crimean-Congo haemorrhagic fever virus in ticks collected from livestock in Balochistan, Pakistan. Transbound. Emerg. Dis. 67, 1543-1552. doi: $10.1111 /$ tbed.13488

Khalid, S., Shahid, M., Bibi, I., Sarwar, T., Shah, A. H., and Niazi, N. K. (2018). A review of environmental contamination and health risk assessment of wastewater use for crop irrigation with a focus on low and highincome countries. Int. J. Environ. Res. Public Health 15:895. doi: 10.3390/ ijerph15050895

Khaliq, A., Khan, I., Akhtar, M., and Chaudhry, M. (2015). Environmental risk factors and social determinants of pulmonary tuberculosis in Pakistan. Epidemiology 5:201.

Khan, J., and Khan, A. (2015). Incidence of dengue in 2013: dengue outbreak in District Swat, Khyber Pakhtunkhwa, Pakistan. Int. J. Fauna Biol. Stud. 2, $1-7$.

Khan, K., Wahid, S., and Khan, N. H. (2019). Habitat characterization of sand fly vectors of leishmaniasis in Khyber Pakhtunkhwa, Pakistan. Acta Trop. 199:105147. doi: 10.1016/j.actatropica.2019.105147

Khan, N. H., Bari, A. U., Hashim, R., Khan, I., Muneer, A., Shah, A., et al. (2016). Cutaneous leishmaniasis in Khyber Pakhtunkhwa province of Pakistan: clinical diversity and species-level diagnosis. Am. J. Trop. Med. Hyg. 95, 1106-1114. doi: 10.4269/ajtmh.16-0343

Khan, S. U., and Hussain, I. (2020). Inequalities in health and health-related indicators: a spatial geographic analysis of Pakistan. BMC Public Health 20:1800. doi: 10.1186/s12889-020-09870-4

Kilpatrick, A. M., and Randolph, S. E. (2012). Drivers, dynamics, and control of emerging vector-borne zoonotic diseases. Lancet 380, 1946-1955. doi: 10.1016/ S0140-6736(12)61151-9

Kim, J., Gedi, V., Lee, S.-C., Cho, J.-H., Moon, J.-Y., and Yoon, M.-Y. (2015). Advances in anthrax detection: overview of bioprobes and biosensors. Appl. Biochem. Biotechnol. 176, 957-977. doi: 10.1007/s12010-015-1625-z

Klumb, C., Scheftel, J., and Smith, K. (2020). Animal agriculture exposures among Minnesota residents with zoonotic enteric infections, 2012-2016. Epidemiol. Infect. 148:e55. doi: 10.1017/S0950268819002309

Kolton, C. B., Marston, C. K., Stoddard, R. A., Cossaboom, C., Salzer, J. S., Kozel, T. R., et al. (2019). Detection of Bacillus anthracis in animal tissues using InBios 
active anthrax detect rapid test lateral flow immunoassay. Lett. Appl. Microbiol. 68, 480-484. doi: 10.1111/lam.13134

Lammie, S. L., and Hughes, J. M. (2016). Antimicrobial resistance, food safety, and one health: the need for convergence. Annu. Rev. Food Sci. Technol. 7, 287-312. doi: 10.1146/annurev-food-041715-033251

Lee, D., and Murphy, H. M. (2020). Private Wells and Rural Health: groundwater Contaminants of Emerging Concern. Curr. Environ. Health Rep. 7, 129-139. doi: 10.1007/s40572-020-00267-4

Lin, S., Fu, Y., Jia, X., Ding, S., Wu, Y., and Huang, Z. (2020). Discovering Correlations between the COVID-19 Epidemic Spread and Climate. Int. J. Environ. Res. Public Health 17:7958. doi: 10.3390/ijerph17217958

Ma, L., Chen, H., Yan, H., Wu, L., and Zhang, W. (2019). Food safety knowledge, attitudes, and behavior of street food vendors and consumers in Handan, a third tier city in China. BMC Public Health 19:1128. doi: 10.1186/s12889-019-7475-9

Majeed, M. M., and Munir, A. (2020). Pakistan: country report on children's environmental health. Rev. Environ. Health 35, 57-63. doi: 10.1515/reveh2019-0087

Mangili, A., Vindenes, T., and Gendreau, M. (2016). "Infectious risks of air travel," in Infections of Leisure, ed. D Schlossberg (Washington, DC: ASM Press), 333-344. doi: 10.1128/microbiolspec.IOL5-0009-2015

McArthur, D. B. (2019). Emerging Infectious Diseases. Nurs. Clin. North Am. 54, 297-311.

McEwen, S. A., and Collignon, P. J. (2018). "Antimicrobial resistance: a one health perspective," in Antimicrobial Resistance in Bacteria from Livestock and Companion Animals, eds S. Schwarz, L. M. Cavaco and J. Shen (Washington, DC: American Society for Microbiology), 521-547.

McMichael, A. J., Patz, J., and Kovats, R. S. (1998). Impacts of global environmental change on future health and health care in tropical countries. Br. Med. Bull. 54, 475-488. doi: 10.1093/oxfordjournals.bmb.a011702

Moayeri, M., Leppla, S. H., Vrentas, C., Pomerantsev, A. P., and Liu, S. (2015). Anthrax pathogenesis. Annu. Rev. Microbiol. 69, 185-208.

Mohammadi, E., and Golchin, M. (2018). Detection of Brucella abortus by immunofluorescence assay using anti outer membrane protein of $19 \mathrm{kDa}$ antibody. Adv. Clin. Exp. Med. 27, 643-648. doi: $10.17219 /$ acem/85081

Nanan, D., White, F., Azam, I., Afsar, H., and Hozhabri, S. (2003). Evaluation of a water, sanitation, and hygiene education intervention on diarrhoea in northern Pakistan. Bull. World Health Organ. 81, 160-165.

Ngeleja, R. C., Luboobi, L. S., and Nkansah-Gyekye, Y. (2017). The effect of seasonal weather variation on the dynamics of the plague disease. Int. J. Math. Math. Sci. 2017, 1-25. doi: 10.1016/j.mbs.2018.05.013

Nieto, N. C., Khan, K., Uhllah, G., and Teglas, M. B. (2012). The emergence and maintenance of vector-borne diseases in the khyber pakhtunkhwa province, and the federally administered tribal areas of pakistan. Front. Physiol. 3:250. doi: 10.3389/fphys.2012.00250

Nisar, M., Mushtaq, M. H., Shehzad, W., Hussain, A., Nasar, M., Nagaraja, K. V., et al. (2018). Occurrence of Campylobacter in retail meat in Lahore, Pakistan. Acta Trop. 185, 42-45. doi: 10.1016/j.actatropica.2018.04.030

Noureen, R. (2018). Knowledge, attitude and practice regarding rabies in rural area of Lahore. Int. J. Sci. Eng. Res. 9.

Ochiai, R. L., Acosta, C. J., Danovaro-Holliday, M. C., Baiqing, D., Bhattacharya, S. K., Agtini, M. D., et al. (2008). A study of typhoid fever in five Asian countries: disease burden and implications for controls. Bull. World Health Organ. 86, 260-268. doi: 10.2471/blt.06.039818

Ondrejková, A., Suli, J., Ondrejka, R., Slepecká, E., Prokeš, M., Čechvala, P., et al. (2015). Detection of rabies antibodies in dog sera. Pol. J. Vet. Sci. 18, 47-51. doi: 10.1515/pjvs-2015-0006

Owczarczak-Garstecka, S. (2018). Understanding risk in human-animal interactions. Forced Migr. Rev. 58, 78-80.

Ozawa, Y. (2003). Risk management of transmissible spongiform encephalopathies in Asia. Rev. Sci. Tech. 22, 237-249. doi: 10.20506/rst.22.1.1397

Pakistan Bureau of Statistics [PBS] (2017). Provisional Summary Results of 6 th Population and Housing Census-2017. Islamabad: Pakistan Bureau of Statistics.

Pandey, S. (2006). Water pollution and health. Kathmandu Univ. Med. J. 4, $128-134$.
Paterson, D. L., Wright, H., and Harris, P. N. A. (2018). Health Risks of Flood Disasters. Clin. Infect. Dis. 67, 1450-1454. doi: 10.1093/cid/ciy227

Patz, J., Githeko, A., McCarty, J., Hussein, S., Confalonieri, U., and De Wet, N. (2003). Climate change and infectious diseases. Clim. Chang. Hum. Health Risks Responses 6, 103-137.

Petrin, C. E., Steele, R. W., Margolis, E. A., Rabon, J. M., Martin, H., and Wright, A. (2020). Drug-Resistant Salmonella typhi in Pakistan. Clin. Pediatr. 59, 31-33. doi: $10.1177 / 0009922819881203$

Qasim, M., Anees, M. M., and Bashir, A. (2014). Unhygienic water is the cause of water borne disease among villagers: a case of Gujrat-Pakistan. World Appl. Sci. J. 29, 1484-1491.

Qin, L., Nan, W., Wang, Y., Zhang, Y., Tan, P., Chen, Y., et al. (2019). A novel approach for detection of brucella using a real-time recombinase polymerase amplification assay. Mol. Cell. Probes 48:101451. doi: 10.1016/j.mcp.2019. 101451

Rab, M. A., Bile, M. K., Mubarik, M. M., Asghar, H., Sami, Z., Siddiqi, S., et al. (1997). Water-borne hepatitis E virus epidemic in Islamabad, Pakistan: a common source outbreak traced to the malfunction of a modern water treatment plant. Am. J. Trop. Med. Hyg. 57, 151-157. doi: 10.4269/ajtmh.1997. 57.151

Rahman, M., Sobur, M., Islam, M., Ievy, S., Hossain, M., El Zowalaty, M. E., et al. (2020). Zoonotic Diseases: etiology, Impact, and Control. Microorganisms 8:1405. doi: $10.3390 /$ microorganisms 8091405

Rossati, A. (2017). Global warming and its health impact. Int. J. Occup. Environ. Med. 8, 7-20.

Rothenburger, J. L., Himsworth, C. G., Nemeth, N. M., Pearl, D. L., Treuting, P. M., and Jardine, C. M. (2019). The devil is in the details-Host disease and co-infections are associated with zoonotic pathogen carriage in Norway rats (Rattus norvegicus). Zoonoses Public Health 66, 622-635. doi: 10.1111/zph. 12615

Saad-Roy, C., Van den Driessche, P., and Yakubu, A.-A. (2017). A mathematical model of anthrax transmission in animal populations. Bull. Math. Biol. 79, 303-324. doi: 10.1007/s11538-016-0238-1

Samad, A., Abbas, F., Ahmad, Z., Pokryrshko, O., and Asmat, T. M. (2018). Prevalence of foodborne pathogens in food items in Quetta, Pakistan. Pak. J. Zool. 50, 1-4.

Shabbir, M. Z., Jamil, T., Muhammad, K., Yaqub, T., Bano, A., MIrza, A. I., et al. (2015). Prevalence and distribution of soil-borne zoonotic pathogens in Lahore district of Pakistan. Front. Microbiol. 6:917. doi: $10.3389 /$ fmicb.2015.00917

Shah, T., Hayat, A., Jadoon, A., Ahmad, S., and Bahadar Khan, S. (2017). Molecular detection of multi drug resistant tuberculosis (MDR-TB) in MDR-TB patients' attendant in North Western Pakistan. PAFMJ 67, 982-987.

Shahid, M., Khalid, S., Murtaza, B., Anwar, H., Shah, A. H., Sardar, A., et al. (2020). A critical analysis of wastewater use in agriculture and associated health risks in Pakistan. Environ. Geochem. Health 1-20. doi: 10.1007/s10653-020-00702-3

Shaikh, B. T., and Hatcher, J. (2005). Health seeking behaviour and health service utilization in Pakistan: challenging the policy makers. J. Public Health 27, 49-54. doi: $10.1093 /$ pubmed/fdh207

Singh, C., and Ahmad, A. (2018). Molecular approach for ante-mortem diagnosis of rabies in dogs. Indian J. Med. Res. 147, 513-516. doi: 10.4103/ijmr.IJMR_ 1705_15

Sleeman, J., Richgels, K., White, C., and Stephen, C. (2019). Integration of wildlife and environmental health into a One Health approach. Rev. Sci. Tech. 38, 91-102. doi: 10.20506/rst.38.1.2944

Sohail, M. L., Khan, M. S., Ijaz, M., Naseer, O., Fatima, Z., Ahmad, A. S., et al. (2018). Seroprevalence and risk factor analysis of human leptospirosis in distinct climatic regions of Pakistan. Acta Trop. 181, 79-83. doi: 10.1016/j. actatropica.2018.01.021

Suk, J. E., Van Cangh, T., Beauté, J., Bartels, C., Tsolova, S., Pharris, A., et al. (2014). The interconnected and cross-border nature of risks posed by infectious diseases. Glob. Health Action 7:25287. doi: 10.3402/gha.v7.25287

Suk, W. A., Ruchirawat, K. M., Balakrishnan, K., Berger, M., Carpenter, D., Damstra, T., et al. (2003). Environmental threats to children's health in Southeast Asia and the Western Pacific. Environ. Health Perspect. 111, 13401347. doi: $10.1289 /$ ehp. 6059 
Supramaniam, A., Lui, H., Bellette, B. M., Rudd, P. A., and Herrero, L. J. (2018). How myeloid cells contribute to the pathogenesis of prominent emerging zoonotic diseases. J. Gen. Virol. 99, 953-969. doi: 10.1099/jgv.0.001024

Tiwananthagorn, S., Bhutto, A. M., Baloch, J. H., Soomro, F. R., Kawamura, Y., Nakao, R., et al. (2012). Zoophilic feeding behaviour of phlebotomine sand flies in the endemic areas of cutaneous leishmaniasis of Sindh Province, Pakistan. Parasitol. Res. 111, 125-133. doi: 10.1007/s00436-011-2808-3

Torquato, R. B., Iamamoto, K., Fernandes, E. R., Achkar, S., Silva, S. R., Katz, I. S., et al. (2020). Detection of rabies virus antigen by the indirect rapid immunohistochemistry test in equines and comparisons with other diagnostic techniques. Zoonoses Public Health 67, 651-657. doi: $10.1111 /$ zph.12745

Turnbull, P. C. B. (2008). Anthrax In Humans And Animals. Geneva: World Health Organization.

Ur-Rehman, S., Arshad, M., Hussain, I., and Iqbal, Z. (2014). Detection and seroprevalence of foot and mouth disease in sheep and goats in Punjab, Pakistan. Transbound. Emerg. Dis. 61, 25-30. doi: 10.1111/tbed. 12194

Velraj, R., and Haghighat, F. (2020). The contribution of dry indoor built environment on the spread of Coronavirus: data from various Indian states. Sustain. Cities Soc. 62:102371. doi: 10.1016/j.scs.2020. 102371

Vincent, A. T., Schiettekatte, O., Goarant, C., Neela, V. K., Bernet, E., Thibeaux, R., et al. (2019). Revisiting the taxonomy and evolution of pathogenicity of the genus Leptospira through the prism of genomics. PLoS Negl. Trop. Dis. 13:e0007270. doi: 10.1371/journal.pntd.000 7270

Vincent, S. S. (2016). Socio-Economic Inequalities and their Impact on Health in Pakistan. Int. J. Res. Nurs. 7, 12-18.

Warraich, H., Zaidi, A. K., and Patel, K. (2011). Floods in Pakistan: a public health crisis. Bull. World Health Organ. 89, 236-237. doi: 10.2471/BLT.10. 083386
World Health Organization [WHO] (2004). Public health response to biological and chemical weapons: WHO guidance. Geneva: World Health Organization.

World Health Organization [WHO] (2017). News: Eap-pd: chikungunya reported in Pakistan. Geneva: World Health Organization.

World Health Organization [WHO] (2018). WHO expert consultation on rabies: third report. Geneva: World Health Organization.

World Health Organization [WHO] (2019). 1 in 3 people globally do not have access to safe drinking water - UNICEF, WHO. News release New York. Geneva: World Health Organization.

Yousaf, M. Z., Ashfaq, U. A., Anjum, K. M., and Fatima, S. (2018). Crimean-Congo Hemorrhagic Fever (CCHF) in Pakistan: the "Bell" is Ringing Silently. Crit. Rev. Eukaryot. Gene Expr. 28, 93-100. doi: 10.1615/CritRevEukaryotGeneExpr. 2018020593

Zahid, J. (2018). Impact Of Clean Drinking Water And Sanitation On Water Borne Diseases In Pakistan. Islamabad: Sustainable Development Policy Institute.

Conflict of Interest: The authors declare that the research was conducted in the absence of any commercial or financial relationships that could be construed as a potential conflict of interest.

Publisher's Note: All claims expressed in this article are solely those of the authors and do not necessarily represent those of their affiliated organizations, or those of the publisher, the editors and the reviewers. Any product that may be evaluated in this article, or claim that may be made by its manufacturer, is not guaranteed or endorsed by the publisher.

Copyright (c) 2022 Yasmeen, Jabbar, Shah, Fang, Aslam, Naseeb, Shakeel, Ahmad, Baloch and Liu. This is an open-access article distributed under the terms of the Creative Commons Attribution License (CC BY). The use, distribution or reproduction in other forums is permitted, provided the original author(s) and the copyright owner(s) are credited and that the original publication in this journal is cited, in accordance with accepted academic practice. No use, distribution or reproduction is permitted which does not comply with these terms. 